\title{
GEOBIOLOGICAL CORAL-REEF STUDIES
}

\section{BY}

\author{
IAN G. MACINTYRE
}

The amazing world of natural history made its first impact on me during World War II on the tropical island of Barbados. My Scottish father had become manager of the British Union Oil Company there, a small outfit that explored for oil and gas on the island and refined crude oil from Venezuela. I had arrived in Barbados in April of 1939, and with the outbreak of war and appearance of German U-boats in the region, my family became trapped on the island. As a result, I spent seven of my formative years in a house in the tropics that had a golf course at the back and the emerald Caribbean Sea a short distance in front. This is where it all began.

The golf course became my hunting ground for butterflies and bird and reptile eggs. What a challenge it was to try to net those elusive butterflies or reach a nest way out on a thin limb. Molluscs were also highly sought after. Sunrise Tellins (Tellina radiata), which we called "auroras" because of their radiating colors, were a special prize. To capture them, I had to pump holes in the shallow back-reef sand with my feet until I could feel one of these slippery bivalves and dive it up. When slit open and spread out to dry, they resembled butterflies.

About the time I started school, I met the "ultimate collector," Dr Alfred Senn, the British Union Oil Company's geologist. I used to spend hours after school watching him picking microfossils - mostly foraminifera, I think - out of samples and filing them in endless rows of small vials. This was the life for me: I decided then and there to become an oil company geologist.

When the war ended, my father, convinced that an 11-year old who was spending all his spare time in trees or in the sea was simply not taking life seriously enough, decided to ship me off to boarding school in Scotland. There I was expected to develop character and apply myself to more serious studies. So in 1946, still set on becoming an oil company geologist, I headed for the land of chilblains.

After completing my secondary education, I turned my gaze to the New World because of the expanding opportunities for work in oil companies there. Though I was accepted at MIT, my father's Scottish roots ran too deep and I entered Queen's University in Canada. Upon graduation in 1957 with a BSc. in geological engineering, I was hired as a stratigrapher in the Exploration Department of Shell Oil Company of Canada in Regina, Saskatchewan (a.k.a. "Saskaberia"). Needless to say, it warmed my heart when I heard that I had been selected to participate in a short course on Recent

Department of Paleobiology, National Museum of Natural History, Smithsonian Institution, Washington, DC 20560-0125 
carbonate sediments in Florida and the Bahamas, under the leadership of Robert N. Ginsburg of Shell Development Company. This course and accompanying field trips (Fig. 1a,b) introduced me to a vast new world of marine science. This is really where I belonged, I thought, but it would take some time to get there.

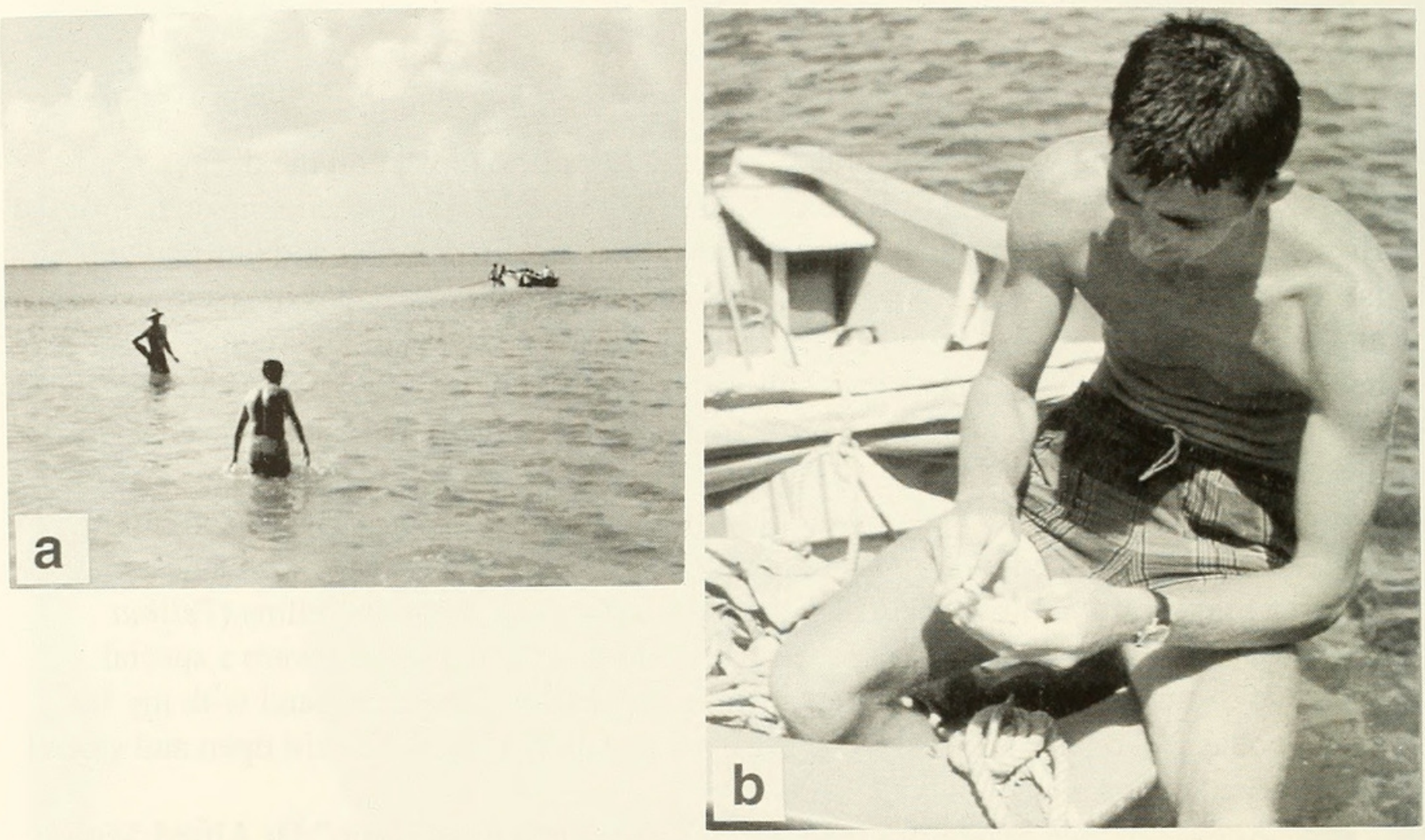

Figure 1. 1959. Shell Development Company Field Trip on Recent Carbonate Sediments: (a) Bob Ginsburg (with hat) encouraging a lagger to wade across a mud bank in Florida Bay. (b) Gene Shinn, Bob's new field assistant, encouraging participants to sample raw conch.

After working for three years on the Mississippian of Saskatchewan, I was transferred to Calgary, Alberta, to work on the Devonian (Fig. 2a). I was eventually assigned to work with Leslie V. Illing, noted at that time for his classic study of Bahamian sediments. I worked with Les on the Devonian of the foothills and Rocky Mountains of Alberta (Fig. 2b). It was during a field trip to show Bob Ginsburg some of our work that I told him that I was interested in modern carbonate studies. He said: "If you are going to make a move, do it now."

This meant abandoning my lucrative but sometimes tedious life as an oil geologist for the meager existence of a graduate student at McGill University. McGill's Bellairs Research Institute in Barbados brought me right back to my old home. It was there, with its director, John B. Lewis, that I collected data for my dissertation on the sediments and reefs off the west coast of the island. The most striking sea-floor topography off this coast consisted of two ridges cresting at $20 \mathrm{~m}$ and $70 \mathrm{~m}$ and running parallel to the entire west coast. This was my first encounter with what I interpreted to be relict submerged coral reefs that probably were flourishing shallow-water reefs during preexisting lower postglacial sea levels (Macintyre, 1967). 

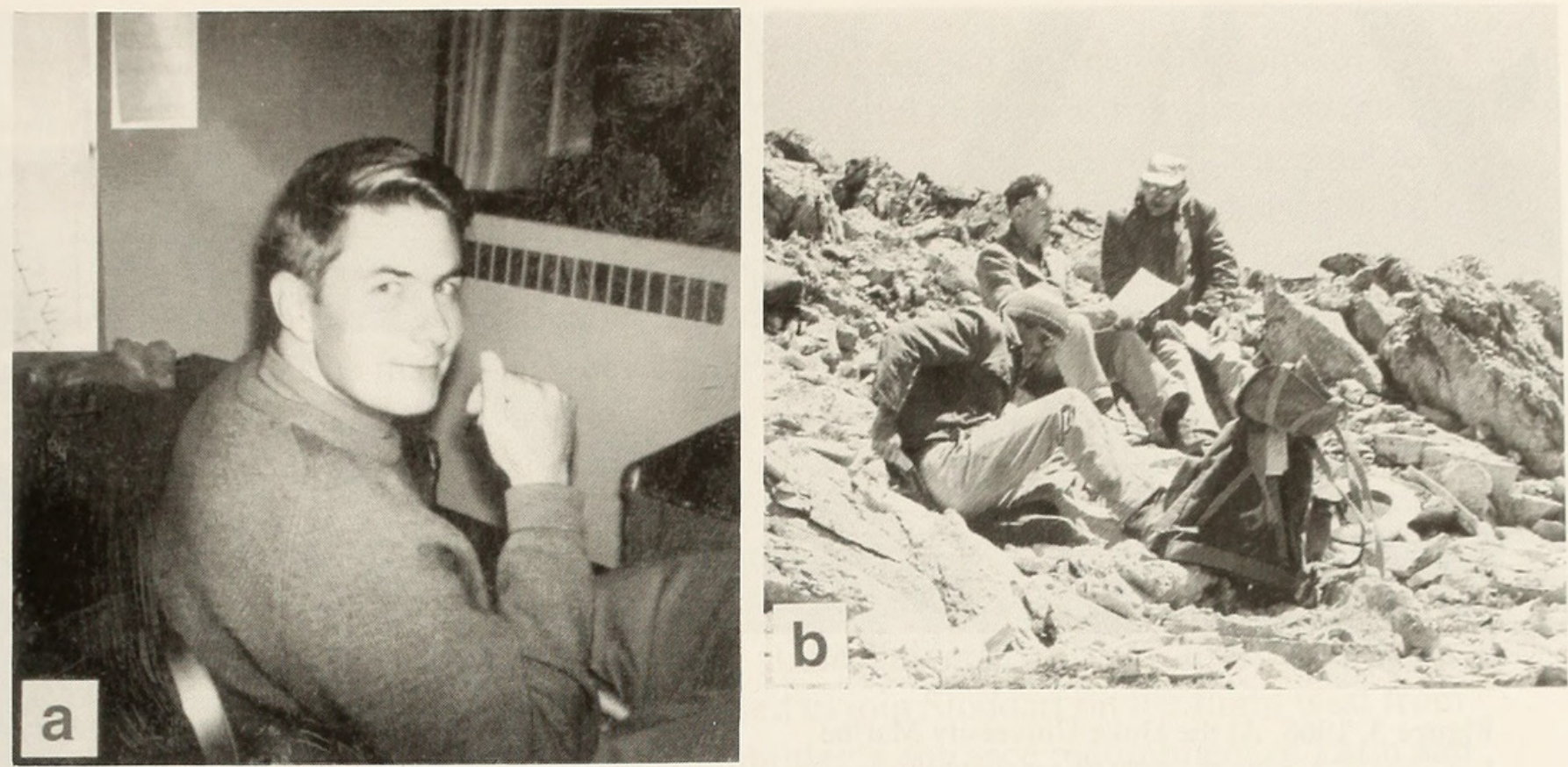

Figure 2. 1962. Working for Shell Oil Company of Canada, in Calgary, Alberta, Canada. (a) In my Exploration Department Office. (b) Mapping with Les Illing (no hat) in the Rocky Mountains.

A short time later, as a postdoctoral fellow (Fig. 3a,b) at the Duke University Marine Laboratory, I collected further data during several Caribbean cruises on the R/V Eastward. I was then able to demonstrate that these relict reef ridges were common features on many of the insular slcpes and shelves of islands in the eastern Caribbean and even off the east coast of Florida (Macintyre, 1972).

There were skeptics aplenty in those days (the late 1960s and early 1970s). The prevailing thought at that time was that the development of Caribbean coral reefs had been restricted by cool postglacial temperatures, and hence that these reefs were less than 5,000 years old, being thin veneers with inherited relief from the substrates on which they were established. So my relict reefs could not be postglacial. It became clear that we needed to see the fossil record preserved within these deeper ridges and the shallow platform reefs if we hoped to arrive at a better understanding of the Holocene history of western Atlantic coral reefs.

It was during my stay at the Duke University Marine Laboratory that, along with Orrin H. Pilkey (Fig. 4a), we discovered numerous patches of tropical reef corals offshore in Onslow Bay, North Carolina (Macintyre and Pilkey, 1969). These patches consisted of Solenastrea hyades and Siderastrea siderea (Fig. 4b), usually established on flat Miocene sandstone outcrops in water depths of 20 to 40 meters. The intriguing question was: how had these corals survived in water temperatures that dropped to less than $16{ }^{\circ} \mathrm{C}$ for three months of the year and also withstood periods of temporary burial by migrating sand waves.

In 1970, I joined the staff of Smithsonian Institution's National Museum of Natural History. My first responsibility was to manage an NSF pre-proposal grant to develop a long-term, multidisciplinary, and multi-institutional proposal to study coralreef ecosystems. This project - Comparative Investigations of Tropical Reef Ecosystems 


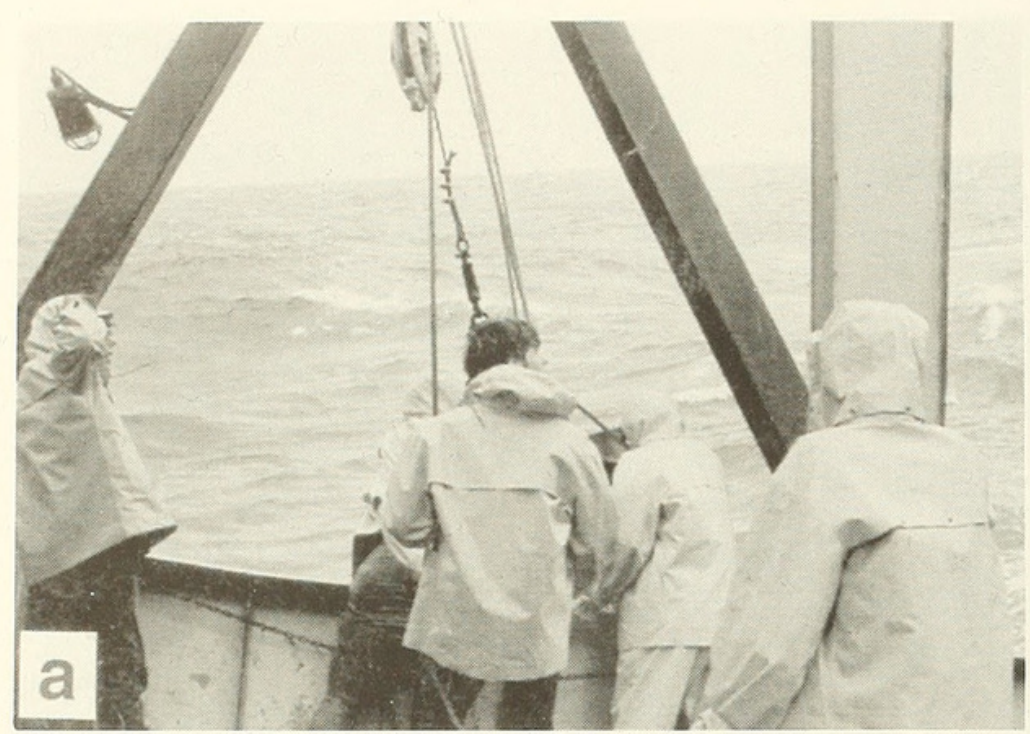

Figure 3. 1968. At the Duke University Marine Laboratory: (a) On the R/V Eastward bringing in rock-dredge samples from a submerged relict reef. (b) At the microscope in my office.

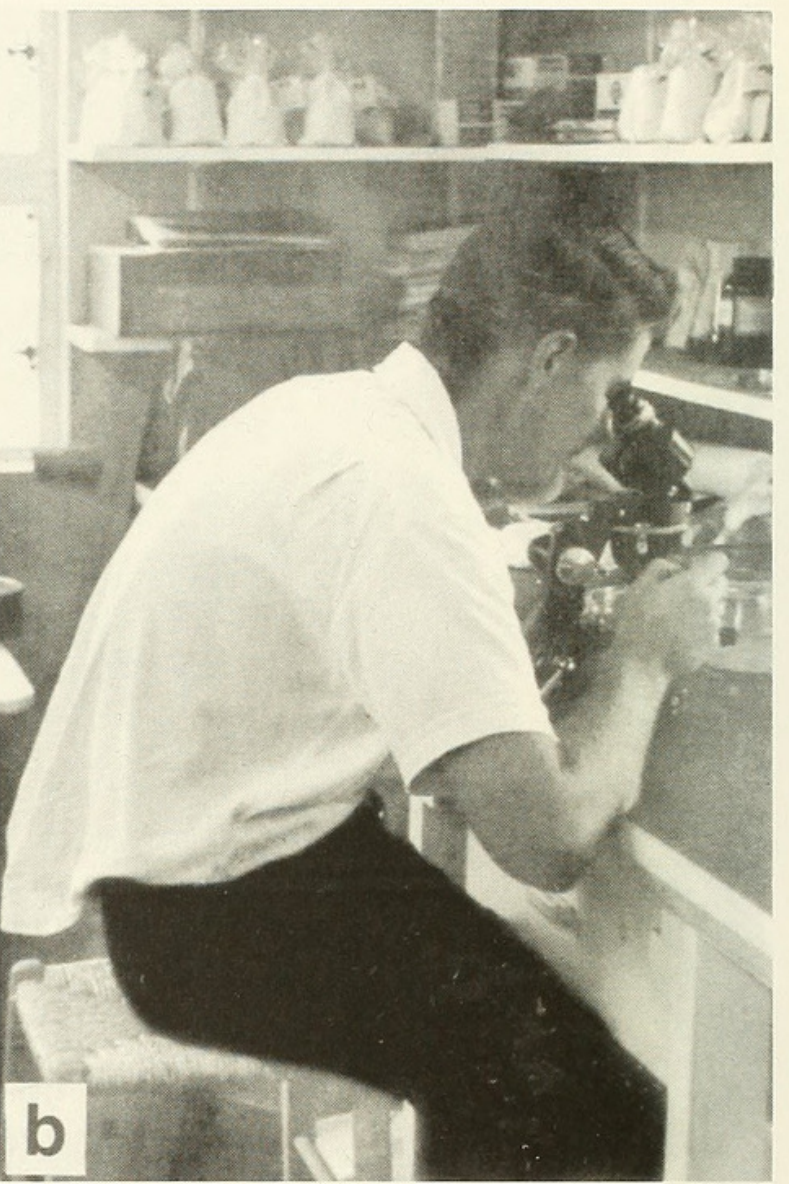

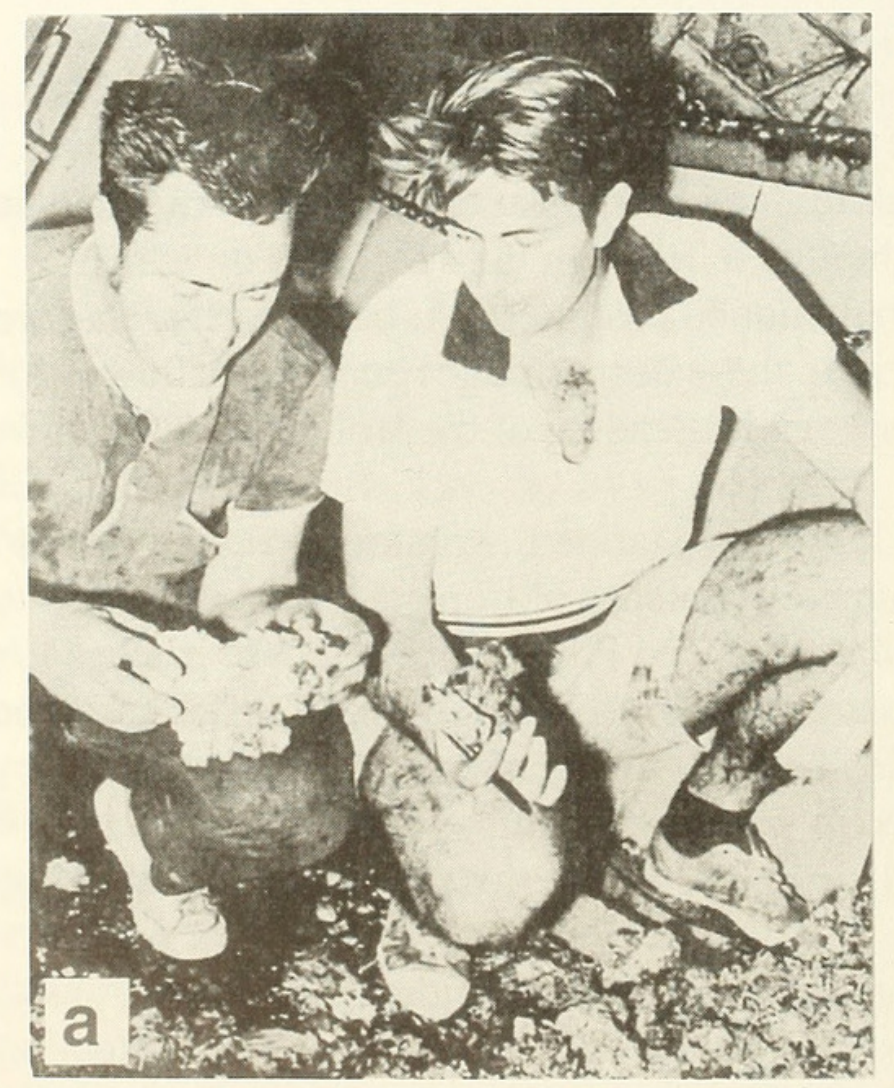

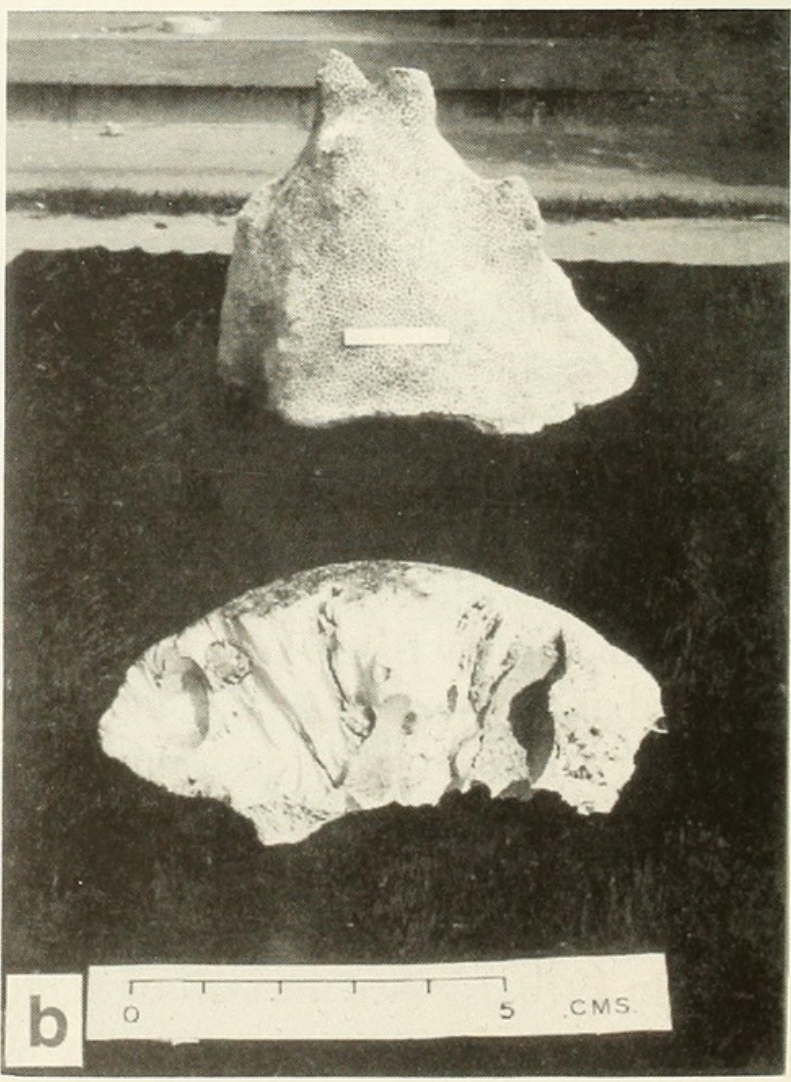

Figure 4. 1968. Tropical reef corals off North Carolina. (a) With Orrin Pilkey inspecting rock-dredge samples. (b) The two corals Solenastrea hyades (top) and Siderastrea siderea (bottom), both scales 5 centimeters. 
(CITRE) - gave me a tremendous opportunity to meet and interact with some of the world's most respected coral-reef scientists. The initial phase was to survey potential reef sites where this work would be undertaken. One of these reef-site visits turned out to be somewhat hazardous. When Walter H. Adey and I set off to check Acklins Island in the southern Bahamas in October 1970, we had to charter a small plane to get there. The airport runway on Acklins was in poor shape, so the pilot decided to land on a recently bulldozed road. As he made his approach, he clipped a large boulder, lost a wheel, and crash-landed. Luckily, there were no injuries to the passengers, but the plane was a wreck. This dramatic arrival may have been a bad omen. We found that the reefs of this area were unsuitable for a research site.

It was during these early stages of developing the CITRE proposal that I also met the renowned David R. Stoddart of Cambridge University. I was in charge of the Geology Working Group, scheduled to meet at the University of Hawaii to discuss our research objectives, and en route was supposed to join Stoddart on the flight west from San Francisco. All I could think of was Cambridge's entrance requirement of Latin and my own lack of talent therein, hoping the conversation wouldn't turn to that subject. Much to my delight, David talked incessantly and enthusiastically about coral reefs and their associated islands - by the time we arrived in Hawaii, we were friends for life!

Then in November of 1971 a two-week workshop took place on Glover's Reef, Belize, where 41 participants (Fig. 5) representing a variety of reef-related disciplines worked on developing a computerized coral-reef ecosystem model that integrated all the various aspects of coral reef research. The model that resulted from this workshop was designed to depict the flow of carbon through a coral-reef ecosystem. Although the proposal was never funded, it proved to be the catalyst for many future studies on coral reefs (Atoll Research Bulletin Nos. 172-73 describing this model have been out of print for many years). Another important contribution resulting from this grant was the discovery of Carrie Bow Cay on the Belizean Barrier Reef, where the National Museum of Natural History established a field station in 1972. This is still a very active field facility, which has provided field support for over 600 publications on coral reef and mangrove investigations.

Part way through the development of this NSF grant, I was officially transferred to Smithsonian's Department of Paleobiology. With the setup funds provided, I was finally given the opportunity to achieve my goal, which was to look inside coral reef frameworks. To this end, I developed a submersible drill by adapting a hydraulic impact wrench to accommodate standard drill equipment (Macintyre, 1974). This drill, which could be operated by three people, would allow us to collect cores across an entire reef transect from the exposed reef flat (Fig. 6a) to the deep fore reef (Fig. 6b). My initial studies of the geological record preserved within coral-reef frameworks were undertaken with Peter W. Glynn off the Caribbean and Pacific coasts of Panama (Macintyre and Glynn, 1976; Glynn and Macintyre, 1977). Here we found out that modern Caribbean fringing coral reefs were not thin veneers but were up to $14 \mathrm{~m}$ thick and were quite capable of forming their own relief. Our success was quickly appreciated and colleagues in the United States, Australia, Japan, and Germany began assembling their own hydraulic drilling equipment to study Holocene coral-reef history. 


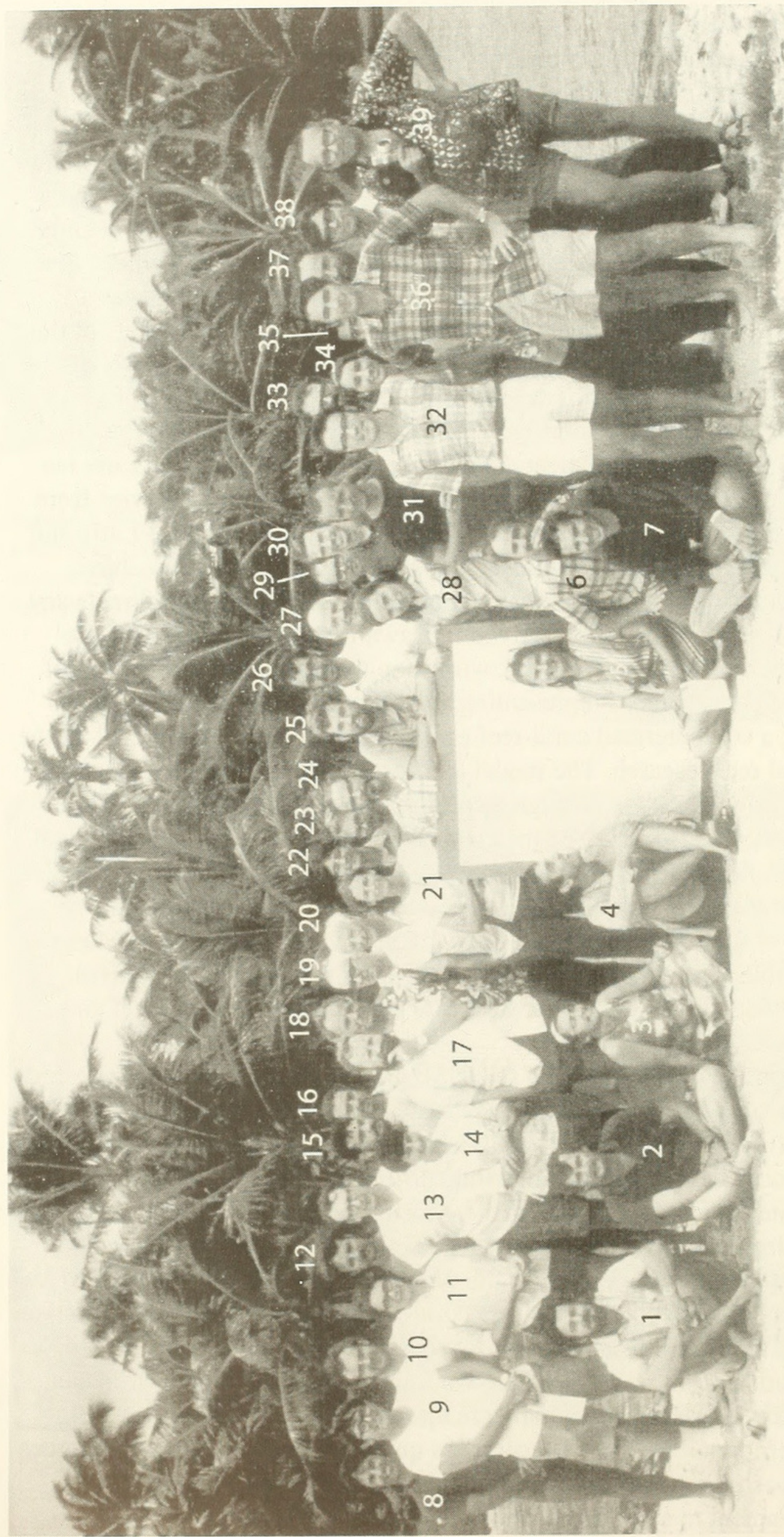

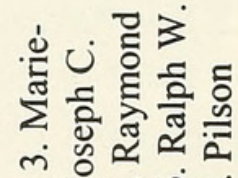

on:

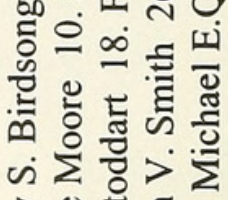

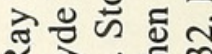

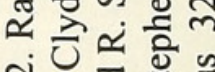

글

ㅁํำ

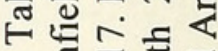

工 ญ

光当的

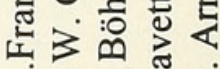

묵 떠

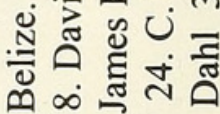

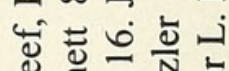

结。苞

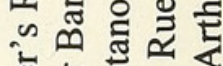

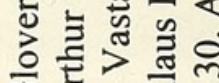

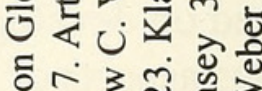

을 는

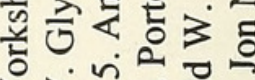

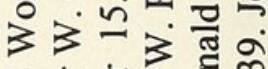

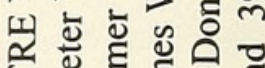

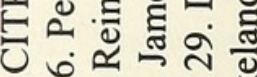
윯ำ

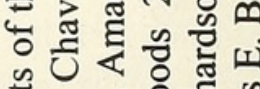

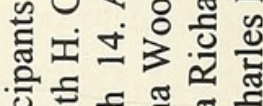

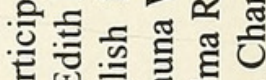
피에웛 顿的严吉 异 $\dot{\sim} \dot{\sim} \infty$ ॠ

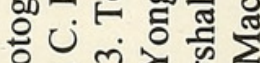
을 页

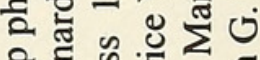

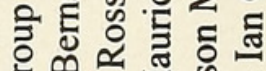

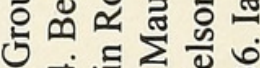
+十

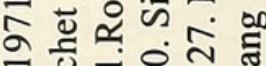
ம் กั

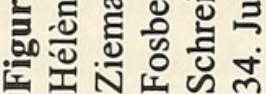



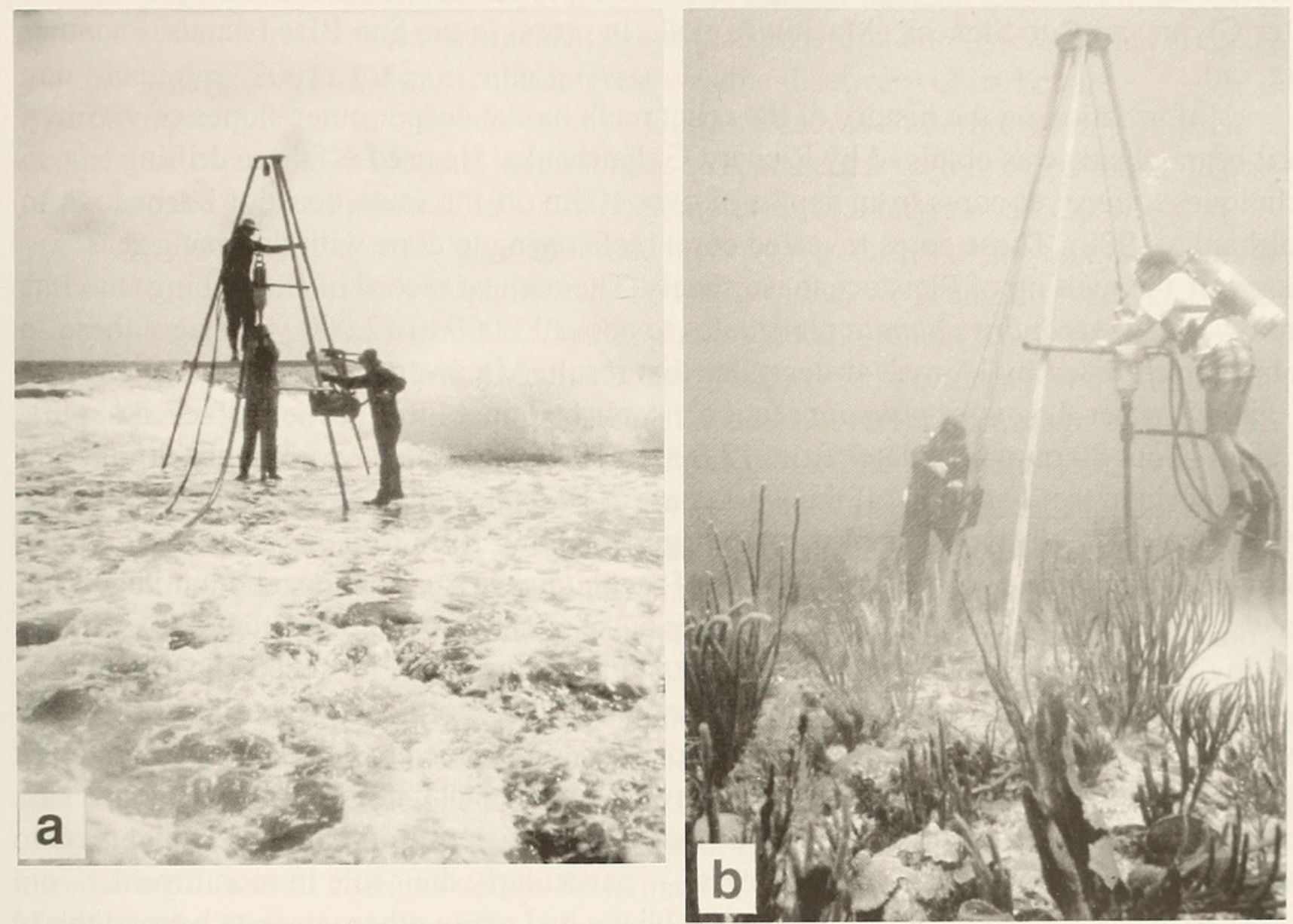

Figure 6. Working with hydraulic-operated coring equipment: (a) Above water drilling the Holandés Ridge, Panamá. 1993. (b) At a depth of 15 meters, coring a relict reef off the southeast coast of St. Croix. 1976.

In 1976, I was able to look at the internal structures of some relict submerged coral reefs. First, with Walter H. Adey (Adey et al., 1977) we drilled a shelf-edge ridge system off the southeastern coast of St. Croix (Fig. 6b); then, with Robin G. Lighty we collected samples from exposure through a shelf-edge ridge that had been dredged by a pipeline company off the east coast of Florida (Lighty et al., 1978). In both cases, we discovered relict shallow-water Acropora palmata reefs that were stranded 7,000 to 8,000 years ago by stress conditions related to the flooding of the inner shelves. By the time conditions improved, the water at the shelf edges was too deep for the shallow-water communities to reestablish. Therefore these shelf-edge ridges were indeed relict Holocene reefs that had flourished some 9,500 to 7,000 years ago.

My work on Holocene reef history continued with Robin G. Lighty on Abaco Bank, Northern Bahamas (Lighty et al., 1980); with Randolph B. Burke in the Gulf of Mexico (Macintyre et al., 1981); Randy Burke and Eugene A. Shinn in Belize (Macintyre etal., 1982; Shinn et al.,1982); with Bill Raymond off Puerto Rico (Macintyre et al., 1983); with H. Gray Multer and others off Antigua (Macintyre et al., 1985; with Randy Burke and Walter Adey in Tague Bay, St. Croix (Burke et al., 1989); in the eastern Pacific with Peter Glynn and Jorge Cortés off mainland Costa Rica, Caňo Island, Cocos Island and the Galápagos Islands(Macintyre et al., 1993); with R. Pamela Reid and 
Robert S. Steneck in the Exumas, Bahamas (Macintyre et al., 1996); and finally with Peter Glynn and Bob Steneck (Macintyre et al., in press) in the San Blas Islands, Panamá (Fig. 6a).

Information on the history of the relict reefs on the deeper outer slopes of Caribbean islands was obtained by Richard G. Fairbanks. He used offshore drilling techniques to recover cores from depths of over $100 \mathrm{~m}$ off the south coast of Barbados (Fairbanks, 1988). These cores revealed coral reefs trying to cope with the rising seas caused by the melting of Pleistocene ice sheets. The earliest record of flourishing shallow-water Acropora palmata reefs dates to about 17,000 to 12,000 years ago; these reefs were stranded by IA melt-water pulse that resulted in a very rapid rise in sea level. A shallow-water Acropora palmata section established on a Pleistocene surface at a depth of about $80 \mathrm{~m}$, which dates from 12,000 to 10,000 years ago, correlates with the relict reef ridge that I studied off the west coast of Barbados many years earlier (Macintyre et al., 1991). Fairbanks' data suggest that this 10-m ridge is a reef that flourished during the relatively stable seas of the younger Dryas chonozone, but that it too was unable to survive a second meltwater pulse (IB) that started about 10,000 years ago. In this major contribution to our understanding of the post-Pleistocene history of Western Atlantic coral reefs, Fairbanks has indicated that more deep-sea drilling is essential not only to document the early history of Holocene reefs but also to record the history of the waters in which these reefs grew. Biologists also need to investigate in more detail the deeper water communities that still flourish on some of these relict reefs and their relationship to shallow shelf reefs - particularly their role in recruitment.

As a carbonate petrologist, however, I have had many other interests beyond the history of coral reefs. One particular challenge has been to document submarine lithification in coral reefs and try to pin down the processes responsible for the precipitation of this Mg calcite and aragonite (Macintyre, 1977; 1984; Macintyre and Marshall, 1988). Many have worked on this problem without arriving at a final answer. At this point, I favor the hypothesis that submarine lithification is related to the release of ammonia by-products associated with the decay of organic material trapped within the reef framework.

In other studies, Richard R. Graus and I have employed computer model simulation techniques to investigate the factors controlling the growth form of colonial corals (Graus and Macintyre, 1976; 1982) and the distributional patterns of coral-reef internal facies (Graus and Macintyre, 1984; 1988; 1998; Graus et al., 1985). Our coral studies demonstrated that the variations in colony shape of Montastraea annularis with depth appears to correlate with the changes in the light field associated with increasing depth. The reef model, which constructed zonation changes, was based primarily on bottom wave velocity and depth (i.e., light), which allowed us to predict storm damage with data on the bottom topography and storm characteristics. From information on the water characteristics of an area, we were also able to replicate the pattern of the internal facies of a reef that had been drilled as well as the zonation patterns of various Caribbean coral reefs.

Some of my other studies have focused on the skeletal mineralogy of some marine organisms. In an investigation of the mineralogy associated with stylasters, Stephen D. Cairns and I found that the carbonate mineralogy there is controlled for the most part by phylogenetic rather than environmental factors (Cairns and Macintyre, 
1992). Likewise, Frederick M. Bayer and I found that the skeletal minerals in a great variety of octocorals are taxonomically rather than environmentally controlled (Bayer and Macintyre, 2001). Of particular interest was the discovery of carbonate hydroxylapatite found in only one family- Gorgoniidae. We interpreted this unusual occurrence of apatite in modern invertebrates to represent a vestige of an earlier history of phosphatic skeletal mineralization in coelenterates (Macintyre et al., 2000).

R. Pamela Reid and I have undertaken extensive studies of the recrystallization of carbonate grains in shallow tropical seas. To our surprise, we found that recrystallization of porous skeletal grains such as Halimeda plates (Macintyre and Reid, 1995) or porcelaneous foraminifera tests (Macintyre and Reid, 1998) occurs when the organism is still alive. In other words, the original skeletal needles or rods break down to form a microcrystalline texture before the grains become part of the sediment floor. This alteration was always thought to be a post-mortem phenomenon. Indeed, further alteration does occur after death (Reid and Macintyre, 1998), much of it related to a micritization process produced by an endolithic cyanobacterium Solentia that fills its microborings with fibrous aragonite concurrently as it penetrates the grains (Reid and Macintyre, 2000).

In addition, I have worked with a multidisciplinary group on the processes involved in the accretion and lamination of modern marine stromatolites in the Exuma area of the Bahamas. These phenomena, it turns out, are related to a complex interaction of cyanobacterial communities that trap sediment grains and then alter them by introducing chemical changes within these mats of trapped sediment(Reid et al., 2000). My particular interest was the role of the endolithic cyanobacterium Solentia that I mentioned earlier. When there is a hiatus in the accumulation of these stromatolites, Solentia extensively bores and infills grains commonly passing from one grain to another welding them together. This process forms the dominant laminated horizons in the Exuma stromatolites (Macintyre et al., 2000). In other words, a microborer, commonly thought of as an agent of destruction, has now been shown to be a major factor in the preservation of well-lithified stromatolites.

Recently I have been working with Richard B. Aronson, William F. Precht, and others in a study of the open-framework reefs of the southern lagoon of the Belizean barrier reef (Aronson et al., 1998). With many simple push cores (Fig.7 a,b), we have shown that recent major changes in the coral communities of this area, related to both white-band disease and bleaching, have not occurred on a regional scale for the last 3,000 years (Aronson et al., in press) and could have some relationship to human activity (Aronson et al., 2000). Similar studies have been extended to the lagoon reefs inside Bocas del Toro, Panamá.

Perhaps one of the greatest rewards of my career has been the opportunity to have participated in a period of major new discoveries in coral-reef research. Even more exciting has been the chance to collaborate with an outstanding group of scientists from across many disciplines. All of these research colleagues can be credited, in part, for the Darwin Medal (Fig. 8) that I received in 1996 from the International Society for Coral Reef Studies.

A full record of my work can be found on the web at: 

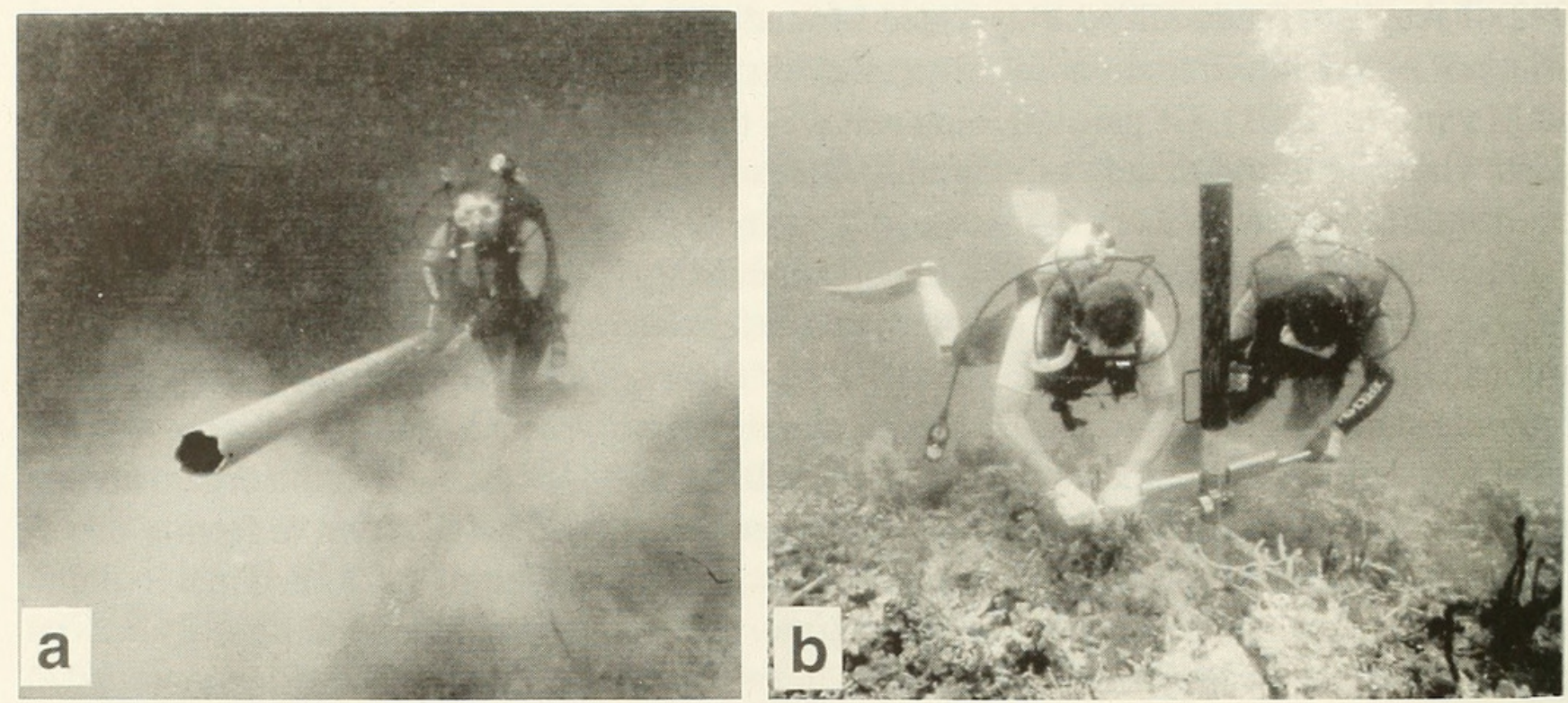

Figure 7. 1997. Push-core studies in Belize: (a) Taking a 5-meter core tube to a core site. (b) Coring with Bill Precht on the left. Note the dark sliding hammer weight on top of the core tube. (Photos by R. B. Aronson)

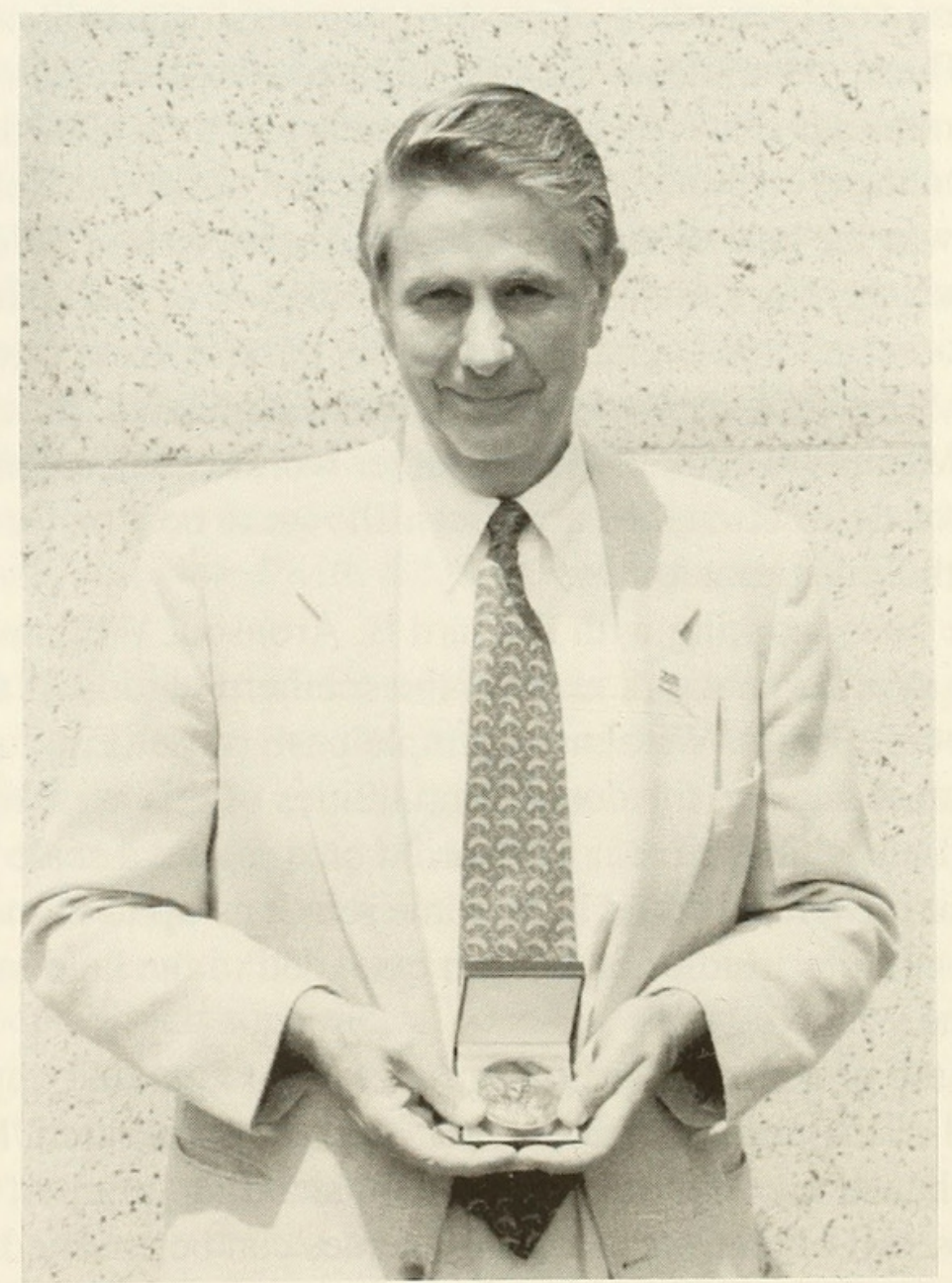

Figure 8. 1996. With the Darwin Medal awarded to me that year by the International Society for Reef Studies. (Photo by W. T. Boykins) 


\section{REFERENCES}

Adey, W.H., I.G. Macintyre, R. Stuckenrath, and R.F. Dill

1977. Relict barrier reef system off St. Croix: Its implications with respect to late Cenosoic coral reef development in the western Atlantic. Proceedings of the Third International Coral Reef Symposium. Atlantic Reef Committee, Miami 2:15-21.

Aronson, R.B., W.F. Precht, and I.G. Macintyre

1998. Extrinsic control of species replacement on a Holocene reef in Belize: The role of coral disease. Coral Reefs 17:223-230.

Aronson, R.B., W.F. Precht, I.G. Macintyre, and T.J.T. Murdoch

2000. Coral bleach-out in Belize. Nature 405:36.

Aronson, R.B., I.G. Macintyre, W.F. Precht, T.J.T. Murdoch, and C.M. Wapnick

In Press. The expanding scale of species turnover events on coral reefs in Belize. Ecological Monographs

Bayer, F.M., and I.G. Macintyre

2001. The mineral component of the axis and holdfast of some gorgonacean octocorals (Coelenterata: Anthozoa), with special reference to the family Gorgoniidae.

Proceedings of the Biological Society of Washington 114:309-345.

Burke, R.B., W.H. Adey, and I.G. Macintyre

1989. Overview of the Holocene history, architecture, and structural components of Tague Reef and Lagoon. Pages 105-109 in D.K. Hubbard (ed). Terrestrial and Marine Geology of St. Croix, U.S.V.I. Special Pub. No. 8 West Indies Laboratory. Tague Bay, St. Croix.

Cairns, S.D., and I.G. Macintyre

1992. Phylogenetic implications of calcium carbonate mineralogy in the Stylasteridae (Cnidaria Hydrozoa). PALAIOS 7:96-107.

Fairbanks, R.G.

1989. A 17,000-year glacio-eustatic sea-level record: Influence of global melting rates on the Younger Dryas event and deep-ocean circulation. Nature 342:637-642.

Glynn, P.W. and I.G. Macintyre

1977. Growth rate and are of coral reefs on the Pacific coast of Panama. Proceedings of the Third International Coral Reef Symposium. Atlantic Reef Committee Miami 2:251-259.

Graus, R. R., and I.G. Macintyre

1976. Light control of growth form in colonial reef corals: Computer simulation. Science 193:895-897.

Graus, R.R., and I.G. Macintyre

1982. Variation in growth forms of the reef coral Montastrea annularis (Ellis and Solander): A quantitative evaluation of growth response to light distribution using computer simulation. Smithsonian Contributions to the Marine Sciences $12: 44-464$.

Graus, R.R., and I.G. Macintyre

1988. The zonation patterns of Caribbean coral reef; as controlled by wave and light Energy input, bathymetric setting and reef morphology: Computer simulation experiments. Coral Reefs 8:9-18. 
Graus, R.R., and I.G. Macintyre

1998. Global warming and the future of Caribbean coral reefs. Carbonates and Evaporites 13:43-47.

Graus, R.R., I.G. Macintyre, and B.E. Herchenroder

1984. Computer simulation of the reef zonation at Discovery Bay, Jamaica: Hurricane disruption and long-term physical oceanographic controls. Coral Reefs 3:59-68.

Graus, R.R., I.G. Macintyre, and B.E. Herchenroder

1985. Computer simulation of the Holocene facies history of a Caribbean fringing Reef, Galeta Point, Panama. Proceedings of the Fifth International Coral Reef Congress. Antenne Museum-EPHE, Moorea, French Polynesia 3:317-322.

Lighty, R.G, I.G. Macintyre, and A.C. Neumann

1980. Demise of the Holocene barrier-reef complex, northern Bahamas. Geological Society of America, Abstracts and Programs 12:47.

Lighty, R.G., I.G. Macintyre, and R. Stuckenrath

1978. Submerged early Holocene barrier reef southeast Florida shelf. Nature 275:59-60.

Macintyre, I.G.

1967. Submerged coral reefs, west coast of Barbados, West Indies. Canadian Journal of Earth Sciences 4:461 474.

Macintyre, 1.G.

1972. Submerged reefs of Eastern Caribbean. American Association of Petroleum Geologists Bulletin 56:720-738.

Macintyre, I.G.

1974. A diver-operated hydraulic drill for coring submerged substrates. Atoll Research Bulletin 185:21-26.

Macintyre, I.G.

1977. Distribution of submarine cements in a modern Caribbean fringing reef, Galeta Point, Panama. Journal of Sedimentary Petrology 47:503-516.

Macintyre, I.G.

1984. Extensive submarine lithification in a cave in the Belize Barrier Reef platform. Journal of Sedimentary Petrology 54:221-235.

Macintyre, I.G., and P.W. Glynn

1976. Evolution of a modern Caribbean fringing reef, Galeta Point, Panama. American Association of Petroleum Geologists Bulletin 60:1054-1072.

Macintyre, I.G., and J.F. Marshall

1988. Submarine lithfication in coral reefs: Some facts and misconceptions.

Proceedings of the Sixth International Coral Reef Symposium. Townsville, Australia 1:263-272.

Macintyre, I.G., and O.H. Pilkey

1969. Tropical reef corals: Tolerance of low temperatures on the North Carolina continental shelf. Science 166:374-375.

Macintyre, I.G., and R.P. Reid

1995. Crystal alteration in a living calcareous alga (Halimeda): Implications for studies in skeletal diagenesis. Journal of Sedimentary Research. A65:143-153. 
Macintyre, I.G., and R.P. Reid

1998. Recrystallization in living porcelaneous foraminifera (Archaias angulatis):

Textural changes without mineralogic alteration. Journal of Sedimentary

Research 68:11-19.

Macintyre, I.G., R.B. Burke, and R. Stuckenrath

1981. Core holes in the outer fore reef off Carrie Bow Cay, Belize: A key to the Holocene history of the Belizean Barrier Reef complex. Proceedings, Fourth International Coral Reef Symposium. University of the Philippines, Quezon City, Philippines 1:567-574.

Macintyre, I.G., P.W. Glynn, and J. Cortés

1993. Holocene reef History in the Eastern Pacific: Mainland Costa Rica, Cano Island, Cocos Island, and Galapagos Islands. Proceedings of the Seventh International Coral Reef Symposium, University of Guam Press, Mangilao, Guam 2:1174-1184.

Macintyre, I.G., P.W. Glynn, and R.S. Steneck

2001. A classic Caribbean algal ridge, Hølandés Cays, Pananá: An algal coated storm deposit. Coral Reefs 20:95-105.

Macintyre, I.G., L. Prufert-Bebout, and R.P. Reid

2000. The role of endolithic cyanobacteria in the formation of lithified laminae in Bahamian stromatolites. Sedimentology 47: 915-921.

Macintyre, I.G., Bill Raymond and R. Stuckenrath

1983. Recent History of a finging reef, Bahia Salina del Sur, Vieques Island, Puerto Rico. Atoll Research Bulletin 268:1-9.

Macintyre, I.G., R.P. Reid, and R.S. Steneck

1996. Growth history of stromatolites in a Holocene fringing reef, Stocking Island, Bahamas. Journal of Sedimentary Research 66:231-242.

Macintyre, I.G., F.M. Bayer, M.A.V. Logan, and H.C.W. Skinner

2000. Possible vestige of early phosphatic biomineralization in gorgonian octocorals (Coelenterata). Geology 28:455-458.

Macintyre, I.G., H.G. Multer, H.L. Zankl, D.K. Hubbard, M.P. Weiss, and

R. Stuckenrath

1985. Growth and depositional facies of a windwardreef complex, Nonsuch Bay, Antigua, W.I. Proceedings of the Fifth International Coral Reef Congress. Antenne Museum-EPHE, Moorea, French Polynesia 6:605-610.

Macintyre, I. G., K. Rützler, J.N. Norris, I.P. Smith, S.D. Cairns, K.E. Bucher, and R.S. Steneck

1991. An early Holocene reef in the western Atlantic: Submersible investigations of a deep relict reef off the west coast of Barbados, W. I. Coral Reefs 10:167-174.

Reid, R.P., and I.G. Macintyre

1998. Carbonate recrystallization in shallow marine environments: A widespread diagenetic process forming micritized grains. Journal of Sedimentary Research 68:928-946.

Reid, R.P., and I.G. Macintyre

2000. Microboring versus recrystallization: Further insight into the micritization process. Journal of Sedimentary Research 70:24-28. 
Reid, R.P., P.T. Visscher, A.W. Decho, J.F. Stoltz, B.M. Bebout, C. Dupraz, I.G. Macintyre, H.W. Paerl, J.L. Pinckney, L. Prufert-Bebout, T.F. Steppe, and D.C. DesMarais

2000. The role of microbes in accretion, lamination, and early lithification of modern marine stromatolites. Nature 406:989-992.

Shinn, E. A., J.H. Hudson, R.B. Halley, B. Lidz, and I.G. Macintyre 1982. Geology and sediment accumulation rates at Carrie Bow Cay, Belize. Smithsonian Contributions to the Marine Sciences 12:63-75. 


\section{$2 \mathrm{BHL}$ Biodiversity Heritage Library}

Macintyre, Ian G. 2001. "Geobiological coral-reef studies." Atoll research bulletin 494, 161-174.

View This Item Online: https://www.biodiversitylibrary.org/item/123661

Permalink: https://www.biodiversitylibrary.org/partpdf/83115

\section{Holding Institution}

Smithsonian Libraries

\section{Sponsored by}

Biodiversity Heritage Library

\section{Copyright \& Reuse}

Copyright Status: In Copyright. Digitized with the permission of the rights holder Rights Holder: National Museum of Natural History, Smithsonian Institution License: https://creativecommons.org/licenses/by-nc-sa/4.0/ Rights: http://www.biodiversitylibrary.org/permissions/

This document was created from content at the Biodiversity Heritage Library, the world's largest open access digital library for biodiversity literature and archives. Visit BHL at https://www.biodiversitylibrary.org. 